\title{
OBČUTLJIVOST EVALVACIJSKIH PRAKS ZA VRSTE, STOPNJE IN PODROČJA ŠTUDIJSKIH PROGRAMOV
}

\section{POVZETEK}

Kakovost v visokem šolstvu je relativna in funkcionalna. Razpeta je med različne interese in hkrati vse manj zavezana univerzi lastnemu jeziku, logiki in vrednotam. Empirična raziskava evalvacijskih praks $v$ Sloveniji prikazuje občutljivost kakovosti za razlike med stopnjami in vrstami študijskih programov ter disciplinami, v katere so študijski programi vpeti. Intrinzična raznoličnost študija je izpeljana tako iz pristopov $v$ visokošolskem izobraževanju, specialnih didaktik in razlik med disciplinami kot iz razlik, ki jih opredeljujejo področni predpisi. Rezultati raziskave na podlagi analize vrednostnih sodb o kakovosti $v$ končnih evalvacijskih poročilih strokovnjakov v postopkih podaljšanja akreditacije študijskih programov sporočajo, da kritičnost in pogostost kvalitativnih poudarkov strokovnjakov slabo sledita nujnostim intrinzičnih posebnosti vrst in stopenj študijskih programov, še posebej pa njihove vpetosti v različne discipline. Ker tudi področna primernost skupin strokovnjakov pri tem skorajda ne nadoknadi neobčutljivosti področnih predpisov za intrinzične posebnosti študija, kakovost ogroža svojevrstnost praks in procesov $v$ visokem šolstvu.

Ključne besede: discipline, evalvacijske prakse, področna primernost strokovnjakov, vrste in stopnje študijskih programov

\section{THE SENSITIVITY OF EVALUATION PRACTICES TO TYPES, CYCLES AND FIELDS OF STUDY PROGRAMMES - ABSTRACT}

Quality in higher education is relative and functional. It is divided between various interests and increasingly less bound to the language, logic, and values of the university. This empirical research of evaluation practices in Slovenia shows the sensitivity of quality to the differences in types and cycles of study programmes as well as their disciplinary foundations. The intrinsic diversity of study is linked to the various approaches that can be found in higher education, to specialist didactics and disciplinary differences, and also to differences nested in legislation. The analysis of quality assessments in the final expert reports from programme re-accreditation procedures shows that the criticism and frequency of qualitative emphases in the reports poorly track the necessities inherent in the intrinsic properties of the types, cycles, and especially disciplinary foundations of study programmes. Since the disciplinary

Mag. Jernej Širok, doktorski študent Filozofske fakultete Univerze v Ljubljani, jernej.sirok@nakvis.si 
competence of evaluators also hardly compensates for the legislation's insensibility to these intrinsic properties, quality endangers the particularity of the practices and processes in higher education.

Keywords: types and cycles of study programmes, disciplines, disciplinary competence of evaluators, evaluation practices

\section{UVOD}

Izrekanje vrednostnih sodb o kakovosti visokega šolstva v delih, ki presegajo ugotavljanje skladnosti s predpisi, je razpeto med ekstrinzičnimi in intrinzičnimi predstavami o tem, kaj je v študijskih praksah in procesih dobro oziroma slabo. Prve vrste predstav zaznamujejo vrednote iz družbenega okolja, v katerem so danes močne poslovna, organizacijska in potrošniška kultura. Te kulture glede na svoje posebnosti od visokega šolstva pričakujejo učinkovitost, produktivnost, uspešnost, optimalnost, storilnost, konkurenčnost, uporabnost, inovativnost, fleksibilnost, odgovornost, transparentnost, sledljivost in dostopnost. Druge vrste predstav se v splošnem ozirajo po akademski svobodi, institucionalni avtonomiji, samoregulaciji vednosti ter predvsem odprtem iskanju resnice in širjenju razuma na najvišji ravni, a se glede na različna področja vednosti, načine poučevanja, vrste izobraževalnih ustanov in študija med seboj razlikujejo.

Kakovost v visokem šolstvu ne temelji na konceptualno poenotenem esencialističnem programu, ki bi za usmerjanje njenega presojanja ponudil strukturiran sistem vrednot, zmožen razlikovanja med ekonomističnimi, tehnokratskimi, konstruktivističnimi in akademskimi ideali kakovostnega. Predstave o dobrem in slabem skuša usmerjati z objektivnimi univerzalnimi predpisi. Ti so pretežno specifikacije družbeno sprejemljivega. So minimalne zahteve, o katerih je mogoče objektivno ugotoviti, ali (in koliko) so izpolnjene. Pomanjkljivo pa usmerjajo vrednotenje kakovosti - tistega, za kar je onkraj ugotovitev o družbeno sprejemljivem mogoče oceniti, da je dobro ali slabo. Kadar evalvacije presežejo preverjanje skladnosti s predpisi in vstopijo v domeno izrekanja vrednostnih sodb, so lahko bodisi meritorne bodisi interesne. Ker se opirajo na različne impulze agensov, vrednote in ideale, so podvržene relativnosti in arbitrarnosti. Kot take trčijo ob tradicije kognitivnih, družbenih in razvojnih posebnosti disciplin, različnih pristopov v visokošolskem izobraževanju, raznovrstnosti študijskih programov in razlik v institucionalni (na primer statusni ali organizacijski) ureditvi visokošolskih zavodov. ${ }^{1}$

Zatekanje k predpisom pri presojanju o kakovosti odpira problematiko njihove specifičnosti in splošnosti. Jasnejši ko je predpis, bolj mora biti specifičen in izključujoč. Bolj ko je splošen, manj natančno je mogoče po njem presojati z upoštevanjem posebnosti presojanega. Če je preveč specifičen, je lahko za posamezne vrste, stopnje

1 Sonja Kump (1994) za označevanje spoznavnih in razumskih gradnikov disciplinarnega znanja uporablja izraz kognitivne lastnosti. Becher in Trowler (2001) uporabljata izraza epistemološke lastnosti in različne oblike znanja. Ker te gradnike poleg epistemoloških dopolnjujejo tudi ontološke in metodološke lastnosti in ker izraz oblike znanja ni dovolj jasen, v nadaljevanju uporabljamo izraz kognitivne lastnosti. 
in področja izobraževanja različno primeren in pravičen. Če nekaterim celo ugaja, je lahko do drugih zaviralen. Če pa je presplošen in univerzalen, pa za posebnosti ni nujno občutljiv. ${ }^{2}$

Kakovost je v Sloveniji uzakonjena. Znotraj upravno-pravnega sistema deloma razlikuje med različnimi stopnjami in vrstami študija ter različnimi vrstami in statusnimi oblikami visokošolskih zavodov, vsem disciplinam in študijskim področjem pa postavlja enake specifikacije. V obdobju, ki ga zajema raziskava evalvacijskih praks, tudi ni bila občutljiva za različne pristope $\mathrm{v}$ visokošolskem izobraževanju. Zato ima potencial za standardizacijo disciplinarne vednosti in uniformiranje njenih partikularnosti, do določene mere pa tudi celotne visokošolske dejavnosti. Medtem ko namreč ni posebej občutljiva za intrinzične posebnosti visokega šolstva, odprto sprejema njemu ekstrinzične vrednote in ideale (Scott, 2003). Ti lahko dajejo prednost izbranim disciplinam (predvsem trdim in aplikativnim), segmentom visoke vednosti (predvsem aplikativni in zaprti vednosti), načinom poučevanja (predvsem usposabljanju in veščinjenju) in vrstam študija (strokovni in specializirani študijski programi). Poleg tega pa lahko izpodrivajo intrinzične vrednote, na primer z zahtevami po učinkovitosti ali preglednosti.

Predpisi se s kakovostjo vednosti, izobraževanja in raziskovanja v njim lastnem jeziku in logiki ukvarjajo obrobno. Primarno se namreč posvečajo participaciji agensov (njihovim pravicam in obveznostim) in pravni ureditvi njihovih medsebojnih transakcij, organizaciji (transparentnost, ureditev organizacijskih ciljev, dokumentacije, procesov, postopkov in nadzora) in poslovanju (učinkovitost in odgovornost). Tako niso le bolje usklajeni z zunanjimi interesi in umeščeni $\mathrm{v}$ upravno-pravni red, temveč se tudi bolje prilagajajo zahtevam po merjenju. Lažje je meriti tisto, kar se meriti dá, in izmerki so javnosti bolj razumljivi, čeprav morda o visokošolskem izobraževanju ne povedo tega, kar bi morali (Biesta, 2010).

Posledice takšnega pristopa h kakovosti so daljnosežne. V vrednostnih sodbah izrečena priporočila, slabosti in pomanjkljivosti se lahko opirajo na različne vrednote ali imperative, tudi tiste, ki so akademskim tuji in za akademske izzive vprašljivi. Sodb, ki bi na primer spodbujale povečanje svobode poučevanja in raziskovanja ali se lotevale problematike razmerja med različnimi pristopi v visokošolskem izobraževanju, v evalvacijskih poročilih ni zaslediti, medtem ko je pozivov k večanju učinkovitosti ali preglednosti na vseh področjih presoje mnogo (Spletni arhiv Nacionalne agencije Republike Slovenije za kakovost v visokem šolstvu, b. d.). Nacionalna agencija Republike Slovenije za kakovost v visokem šolstvu (v nadaljevanju: Agencija) visokošolske zavode $\mathrm{k}$ usmeritvam iz teh sodb praviloma zaveže tako, da jih primora $\mathrm{k}$ realizaciji predlaganih ukrepov pred izdajo končne odločitve o akreditaciji, ali pa z zahtevo za izdelavo akcijskih načrtov, katerih realizacijo bo morda nekoč preverjala (Spletni arhiv Nacionalne agencije Republike Slovenije za kakovost v visokem šolstvu, b. d.).

2 Sonja Kump (1994) je opozorila, da so unitarni kriteriji ali standardi do disciplin krivični, ker ne upoštevajo različne narave disciplin in njihovih predmetov. 
Pri iskanju odgovorov o posledicah instrumenta kakovosti za samobitnost visokega šolstva poskušamo najprej ugotoviti, koliko so strokovnjaki občutljivi za razlike med stopnjami in vrstami študijskih programov ter disciplinami, v katere so študijski programi vpeti. Zanima nas tudi, ali področna primernost skupin strokovnjakov, ki je opredeljena na koncu poglavja Empirični del, na to kakor koli vpliva. Kolikor dopuščajo rezultati, je treba raziskati tudi implikacije takšne občutljivosti. Rezultati raziskave, ki so bili podlaga za ta prispevek, ne zajemajo problematike različnih pristopov v visokošolskem izobraževanju, saj je bila njihova raznoličnost besedišču instrumenta kakovosti v obdobju, ki ga raziskava pokriva, povsem tuja. Zaradi neraziskanosti vzročnih povezav med izsledki evalvacijskih praks in statusom visokošolskih zavodov (predvsem na osi javni-zasebni) raziskava prav tako zaobide občutljivost evalvacijskih praks za posebnosti institucionalne ureditve visokošolskih zavodov, ki izvajajo presojane študijske programe.

\section{POSEBNOSTI DISCIPLINARNE VEDNOSTI IN VISOKOŠOLSKEGA IZOBRAŽEVANJA}

Predpisane specifikacije, na katere se opira instrument kakovosti, ne ločijo med kognitivnimi, družbenimi in razvojnimi posebnostmi disciplin. Celotno evalvacijsko besedišče, vključno s svojimi kvalitativnimi in kvantitativnimi oznakami, določili in usmeritvami tako v Zakonu o visokem šolstvu (v nadaljevanju: ZViS) kot v Merilih za akreditacijo in zunanjo evalvacijo visokošolskih zavodov in študijskih programov (v nadaljevanju: Merila za akreditacijo), nima neposrednih sredstev, ki bi usmerjala prepoznavo in presojo posebnosti glede na disciplino, $v$ katero se umešča študijski program. Merila za akreditacijo iz 2014 v 1. točki 14. člena določajo zgolj, da mora biti študijski program »sestavljen formalno in vsebinsko ustrezno po študijskih področjih ter znanstvenih ali umetniških disciplinah, za katere je zavod ustanovljen « (Merila za akreditacijo in zunanjo evalvacijo visokošolskih zavodov in študijskih programov, 2014). V splošnem določilo usmerja v ugotavljanje ustreznosti (ne kakovosti), ki pa vendarle ni le formalna, temveč tudi vsebinska. Instrument kakovosti se je pri tem zanašal na okoliščino, da so strokovnjaki praviloma habilitirani visokošolski učitelji s področij presojanih študijskih programov, da so torej člani istih ali vsaj sorodnih disciplin. To naj bi omejevalo vplive, ki bi lahko s svojo neobčutljivostjo, kot opozarja Sonja Kump (1994), prispevali k rušitvi zvez med disciplinarnimi skupnostmi in oblikami vednosti.

Kuhn (1996), Biglan (1973), Kolb (1981) ter Becher in Trowler (2001) so bistveno prispevali k razumevanju kognitivnih, družbenih in razvojnih lastnosti oblik disciplinarne vednosti. V kognitivnem smislu se discipline med seboj povezujejo oziroma razlikujejo glede na svoje ontološke, epistemološke in metodološke posebnosti. Kolb (1981) je te lastnosti izpeljal iz različnih strategij iskanja resnice, iz disciplin dominantne filozofije, teorije resnice, skupnih lastnosti temeljnih raziskovalnih vprašanj, temeljnih enot znanja ter različnih načinov njegovega prikazovanja. Discipline tako zaznamujejo specifični kriteriji znanstvenega spoznanja in utemeljevanja. Razlikujejo jih posebna pravila in postopki produkcije, urejanja in preverjanja znanja. Medtem ko ene stremijo k odkritjem ali 
aplikativnim rešitvam, so pri drugih odkritja in tehnologije v praksi redki, njihova znanstvena prizadevanja pa skušajo širiti ali poglabljati razumevanje. Odnos do resnice je zato različno strog in sega od približevanja razumevanju realnosti s pomočjo interpretacije do njenega neposrednega dokazovanja in preverjanja (Becher in Trowler, 2001). Medtem ko nekatere discipline $\mathrm{k}$ raziskovanju pristopajo bolj sistematično, objektivno in eksaktno, z bolj nadzorovanimi in izoliranimi spremenljivkami znotraj omejenih referenčnih okvirov, so druge pri tem bolj splošne, celovite, metanarativne in približne, saj je njihov referenčni okvir, v katerem preučujejo medsebojno povezane in odvisne spremenljivke, širši, in dopuščajo različne poglede na resnico (Dilthey, 1990). Raznoličnost zato bogatijo tudi odgovori na raziskovalna vprašanja, ki so glede na značilnosti discipline lahko dokončni ali bolj odprti; različno ločljivi, delni ali bolj celoviti; bolj teoretski ali bolj praktični; prav tako pa jih je mogoče načrtovati in predvidevati z različno zanesljivostjo (Becher in Trowler, 2001). Avtorja dodajata, da je razvoj disciplinarne vednosti lahko bodisi bolj linearen, povezan in kumulativen bodisi ga pretežno zaznamujejo vzorci ponavljanja in skromnejša povezanost ustvarjene vednosti. Kot poleg Biglana, Kolba, Becherja in Trowlerja poudarja Freitag (1996), izvira pomenljiva ločnica tudi iz odnosa disciplin do funkcionalnosti znanja, kar se odraža v različnem razmerju do zainteresirane in nezainteresirane produkcije znanja ter $\mathrm{v}$ pogledu na to, kdaj znanost na poti od produkcije do aplikacije znanja preide $\mathrm{v}$ stroko ter kdaj je znanost predana preučevanju realnosti in kdaj njenemu ustvarjanju.

V družbenem smislu je mogoče discipline razumeti kot kulture posebnih znanstvenih skupnosti, povezane s splošnimi vrednotami in idejami, kot sta akademska svoboda in avtonomija, a razmejene s specifičnimi tradicijami, etiko, pravili vedenja, lingvističnimi in simboličnimi oblikami komuniciranja ter načini prenašanja znanja. Od discipline do discipline tako variirajo medsebojna povezanost in enotnost njihovih članov, prepustnost disciplinarnih meja ter interakcija med disciplinami kot tudi enotnost oziroma razpršenost raziskovalnih interesov in raziskovanja, intelektualnih stilov in diskurzov. Glede na to se, kakor pišeta Becher in Trowler (2001), členijo na urbane in ruralne ter na konvergentne in divergentne. Imajo različne oblike akademskega kapitala, različen status in družbeno moč, ki vplivajo na produkcijo znanja, vrednost in vrednotenje znanstvenih dosežkov ter posledično na akademski uspeh in ugled njihovih članov (Becher in Trowler, 2001; Kolb, 1981).

Kuhn (1996) izpelje razlike $\mathrm{v}$ razvoju disciplinarne vednosti iz dinamike znanstvenih revolucij in linearnosti normalne akumulacije znanstvene vednosti v naravoslovju. Razvojno dinamiko opre na koncept znanstvene paradigme kot temeljne enote znanstvenega razvoja, ki po eni strani povezuje kognitivne in družbene lastnosti znanstvenega dela ter člane posamezne discipline, po drugi pa jo je mogoče razumeti kot nosilko konkretne rešitve nepremostljivega znanstvenega problema ali uganke, ki v izjemnem prelomu spodkoplje tradicijo znanstvenih praks, torej tradicijo kognitivnih in posledično družbenih lastnosti disciplin, ter jih spremeni. Izmenjavo kumulativnih (normalnih) in nekumulativnih (revolucionarnih) epizod strni $\mathrm{v}$ tri razvojne faze disciplin $-\mathrm{v}$ predparadigmatično, 
paradigmatično in poparadigmatično. Ugotavlja, da v njihovem cikličnem izmenjevanju variirajo predvsem: enotnost znanstvenih praks in članov disciplinarnih skupnosti (divergentnost in konvergentnost); število znanstvenih šol, načinov reševanja znanstvenih problemov in pogledov na svet; vloga, pomen ter vpliv disciplinarnih pravil in standardov; načini uvajanja v disciplino; stabilnost, čvrstost, rigidnost in prepustnost disciplin; hitrost oziroma jakost razvoja vednosti ter predvidljivost in prodornost raziskovanja. Kot tudi sam prizna, $\mathrm{z}$ usmeritvijo $\mathrm{v}$ preučevanje razvoja normalnih znanosti zaobide razvojno dinamiko disciplin, ki so že v svojem bistvu divergentne in ciklične ter jim v obdobju normalnega razvoja ne vlada ena povezujoča paradigma. Becher in Trowler (2001) dodata, da takšne discipline kljub temu ne obtičijo zaklenjene v predparadigmatično razvojno fazo in se kot manj vredne ne izključujejo iz polja znanstvenih disciplin. Divergentnost je celo svojevrstno gonilo njihovega napredka, medtem ko jih lahko prizadevanja za enotno paradigmo razvojno omejujejo.

Ker raziskava evalvacijskih praks gravitira k posebnostim vrednostnih sodb pri presojah študijskih programov, vpetih $\mathrm{v}$ različne discipline, se posvetimo še klasifikaciji disciplin glede na kognitivne lastnosti disciplinarne vednosti. Discipline, klasificirane po lastnostih teritorijev disciplinarnega znanja, je namreč mogoče povezati z evidentiranimi študijskimi področji presojanih študijskih programov. Biglan (1973), Kolb (1981) ter Becher in Trowler (2001) poudarjajo, da klasifikacije disciplin niso absolutne in brezčasne, temveč so grobi in spremenljivi konstrukti s prožnimi mejami, ki ne zajemajo vseh kognitivnih posebnosti in kompleksnosti disciplinarne vednosti. Zato discipline, kot je ekonomija, celo omenjeni avtorji pripisujejo različnim skupinam disciplin. Biglan (1973) je z raziskavo dojemanja disciplinarne vednosti med člani različnih akademskih skupnosti discipline razdelil na trde čiste, mehke čiste, trde aplikativne in mehke aplikativne. Kolb (1981) je sledil Biglanovi klasifikaciji, a je skupne lastnosti in razlike med disciplinami namesto v dojemanju članov akademske skupnosti iskal v stilih učenja. Na podlagi lastnosti prenosa disciplinarne vednosti je discipline klasificiral $\mathrm{v}$ abstraktne refleksivne, konkretne refleksivne, abstraktne aktivne in konkretne aktivne. Navezal se je na Biglana in mehke discipline označil za konkretne, trde za abstraktne, aplikativne za aktivne in čiste za refleksivne. Becher (1994) je njunima klasifikacijama pripisal disciplinarna področja, in sicer na način, da trde čiste oziroma abstraktne refleksivne discipline pretežno pokrivajo naravoslovne vede, mehke čiste oziroma konkretne refleksivne zajemajo humanistiko in družbene vede, trde aplikativne oziroma abstraktne aktivne obsegajo znanstvene stroke ( v izvirniku: »science-based professions «), mehke aplikativne oziroma konkretne aktivne pa družbene stroke (v izvirniku: »social professions«).

Trde čiste discipline zaznamujejo kumulativnost, atomističnost, drevesna struktura, zanimanje za univerzalnosti, naravnanost na količine, poenostavitve, brezosebnost in odsotnost vrednot, jasnost pravil za preverjanje znanja in njegove aktualnosti, konsenz za obravnavo pomembnih vprašanj, usmerjenost $\mathrm{v}$ odkritja ter dobra organiziranost. Mehke čiste discipline so reiterativne, holistične, tekoče, usmerjene v partikularnosti, kvalitativne lastnosti in komplikacije. So osebne in polne vrednot. Primanjkuje jim soglasja o 
pomembnih vprašanjih, njihovi rezultati pa so interpretacije. So individualistične, pluralistične in ohlapno strukturirane. Trde aplikativne discipline so namenske, pragmatične in usmerjene v obvladovanje fizičnega okolja. Njihovi pristopi so hevristični, kvalitativni in kvantitativni, pri čemer za kriteriji presoje tičita namen in funkcija. Producirajo izdelke, tehnike in patente. Mehke aplikativne discipline pa poleg namenskosti, pragmatičnosti in oziranja navzven povezuje usmeritev v izboljševanje strokovnih praks. Pomembne so jim študije primerov, producirajo pa protokole in postopke. Podvržene so modam in trendom ter nagnjene k negotovemu statusu (Becher, 1994; Becher in Trowler 2001).

Klasifikacija disciplin po lastnostih teritorijev disciplinarnega znanja upošteva tudi skupne lastnosti in razlike, ki izhajajo iz družbenih in razvojnih posebnosti disciplin ter so jih omenjeni avtorji sicer strukturirali ločeno od kognitivnih. Čeprav so posamezne discipline na družbeni in razvojni ravni klasificirali posebej, so družbene in razvojne lastnosti disciplin povezane $\mathrm{z}$ njihovimi kognitivnimi danostmi. Zato je mogoče $\mathrm{v}$ trdih čistih in trdih aplikativnih disciplinah zasledovati prevlado elementov konvergentnosti, urbanosti in paradigmatične poenotenosti. Zaradi kognitivnih lastnosti tovrstnih disciplin se njihovi člani nagibajo k večji povezanosti, enotnosti in usmerjenosti raziskovanja, pri čemer se te discipline uspešneje razmejujejo od drugih. Nasprotno se mehke čiste in mehke aplikativne discipline nagibajo $\mathrm{k}$ prepustnosti in odprtosti svojih meja ter paradigmatični odprtosti in fragmentiranosti, njihovi člani pa so manj povezani, poenoteni in raziskujejo na širšem področju.

Razsežnost raznoličnosti disciplinarne vednosti poraja pomislek o dopustnosti enotnih objektivnih in merljivih pogojev za presojo kakovosti raziskovalnega oziroma umetniškega dela $v$ visokem šolstvu. Posebnosti disciplinarne vednosti pa pomembno vplivajo tudi na načine prenosa znanja - na visokošolsko izobraževanje. Kolb (1981) razlikuje med disciplinami, ki se pretežno opirajo na modele, teorije in simbolno manipulacijo, in tistimi, ki jim je pomembna čustvenost, intuicija in metaforična reprezentacija znanja. Pri prvih gre za abstraktne oziroma trde discipline, pri drugih pa za konkretne oziroma mehke. Gurung, Chick in Haynie (2009) pa poudarjajo pomen signaturne pedagogike, ki pomeni disciplinarno pogojene specialne didaktike. Avtorji opozarjajo na negativne posledice generičnih pristopov v visokošolskem poučevanju. Prikazujejo kvalifikacijske, predvsem pa socializacijske in subjektifikacijske lastnosti poučevanja, na katere vplivajo disciplinarne kulture in ki se kažejo v različnih tehnikah poučevanja, načinih razmišljanja in razumevanja ter $\mathrm{z}$ njimi povezanih navadah in vrednotah, na podlagi katerih posameznik usvaja disciplinarno specifičen akademski habitus, a obenem tudi razvija metadisciplinarno zavest.

Poleg disciplinarnih posebnosti visokošolskega izobraževanja so pomembni tudi različni idejni pristopi v izobraževanju, ki imajo svojevrsten odnos do kvalifikacije, socializacije in subjektifikacije. ${ }^{3}$ Segajo od omike (»Bildung «) do usposabljanja, od razvijanja akademskega habitusa do razvijanja strokovnega in poslovnega habitusa ter od umeščanja

3 Koncept kvalifikacije, socializacije in subjektifikacije je povzet po Biesta (2010). 
v obstoječi družbeni red do emancipacije (Biesta in Bingham, 2010). ${ }^{4}$ Ker jim botruje uzakonjeno načelo svobode poučevanja, je med njimi mogoče svobodno izbirati, a je nekaterim mogoče tudi dajati večjo pozornost in podporo. Idejni pristopi v visokošolskem izobraževanju so različnim disciplinam različno blizu predvsem glede na to, ali so čiste ali aplikativne in ali so konvergentne ali divergentne.

Gurung idr. (2009) opozarjajo na problem generičnih pristopov v visokošolskem poučevanju, ki niso občutljivi za disciplinarne posebnosti. Kot dodajajo, so ti vse bolj pod vplivom visokemu šolstvu ekstrinzičnih vrednot in namesto specialnih didaktik v ospredje postavljajo vprašanja učinkovitosti in uspešnosti študija ter splošne ideale usposobljenosti za delovno mesto. »[K]olikor bolj [...] so 'kompetence' primarni [...] cilj izobraževanja, toliko bolj se mora temu prilagoditi poučevanje in v svoji skrajni različici postane zgolj trening 'kompetenc.' «(Kotnik, 2013, str. 25) Kompetentnost, kot ugotavlja Kotnik (2013), preprosto gledano pomeni usposobljenost.

Ko preidemo k posebnostim visokošolskega izobraževanja, ki jih nacionalni predpisi vendarle prepoznajo, moramo ugotoviti, kako in s kakšno občutljivostjo se specifikacije in morebitna idejna sidrišča za izrekanje vrednostnih sodb za različne stopnje in vrste študijskih programov opredeljujejo do razmerja med kvalifikacijo, socializacijo in subjektifikacijo. Večina opredelitev različnih stopenj in vrst študija je namenjenih kvalifikaciji, torej se pri vseh namen študija pretežno usmerja v usposobljenost za opravljanje dela.

ZViS (2017) v 33. členu največ določil namenja usposobljenosti. Ta ureditev velja tudi za obdobje, ki ga zajema raziskava. Visokošolske strokovne in univerzitetne študijske programe prve stopnje enači s specifikacijo prenosa strokovnega znanja, uporabe znanstvenih metod, reševanja strokovnih problemov in praktičnega izobraževanja, ki pri univerzitetnih študijskih programih sicer ni obvezno. Univerzitetne študijske programe od visokošolskih strokovnih loči predvsem po dodatni specifikaciji študija teoretičnih in metodoloških konceptov. Magistrski študij se glede na prvostopenjskega na ravni prenosa strokovnega znanja poglobi in razširi - ne specializira. Študij kljub temu ostaja strokoven in šele na tretji stopnji preide na raven znanstvenega izobraževanja, raziskovanja, razvijanja novega znanja, reševanja najzahtevnejših problemov in iskanja rešitev. Socializacija, ki jo ZViS (2017) glede na kvalifikacijo skromneje opredeljuje, je na prvi in drugi stopnji tesno povezana z usposabljanjem za strokovno delo. Medtem ko prvostopenjski študij ne glede na vrsto predvideva odgovornost, samostojnost in iniciativnost $\mathrm{v}$ stroki, je pri magistrskem pomembna predvsem odgovornost. Regresija socializacijske ravni se nadaljuje na doktorskem študiju, kjer ta raven ni opredeljena. Posebnosti študija so na subjektifikacijski ravni še skromneje opredeljene. Za vse njegove stopnje in vrste je zahtevana kritičnost, ki od strokovne kritičnosti na prvostopenjskem študiju prehaja h kritični refleksiji na študiju druge in tretje stopnje.

Slovensko ogrodje kvalifikacij (v nadaljevanju: SOK), kot izdaja že ime, med vrstami in stopnjami študija razlikuje predvsem po elementih usposobljenosti. Medtem ko v ničemer

4 Zgodovinski razvoj humanističnega koncepta izobrazbe pregledno prikaže Kodelja (2010). 
ne razločuje med vrstama prvostopenjskega študija, pri opredeljevanju kompetenc za različne stopnje študija sledi ZViS (SOK, b. d.).

Merila za akreditacijo (2014) v 4. točki 14. člena določajo, da morajo biti »[t]emeljni cilji in učni izidi programa [...] v skladu z vsebino in ravnijo študijskega programa ... Po eni strani predpis namesto upoštevanja posebnosti različnih stopenj in vrst študija tako v zasnovi kot izvedbi poudarja zgolj vsebinsko skladnost zapisov o temeljnih ciljih in učnih izidih z zapisi o vsebini študija na ravni načrtovanja kurikuluma. To se je odražalo tudi v zunanjih evalvacijah študijskih programov, saj 22. člen Meril za akreditacijo (2014) presojo kakovosti študijskih programov usmerja k presoji njihove organizacije in izvedbe, ki pa jo je v odsotnosti kakršnih koli dodatnih določil posebej za izvajanje študija mogoče opreti le na akreditirano stanje in spremembe študijskih programov, torej na omenjeno določilo v 14. členu. Tako na tem področju presoje ne presenečajo številne ocene strokovnjakov, da morajo visokošolski zavodi popraviti zapise $\mathrm{v}$ učnih načrtih (Spletni arhiv Nacionalne agencije Republike Slovenije za kakovost v visokem šolstvu, b. d.). Po drugi strani pa Merila za akreditacijo (2014) v 4. točki 14. člena posebnosti ravni študijskega programa, ki je oprta na klasifikacijski sistem in ne omogoča razlikovanja med vrstami študijskih programov, povezujejo zgolj s temeljnimi cilji in učnimi izidi, ne pa tudi s študijskimi vsebinami, posebnostmi disciplinarne vednosti, iz njih izhajajoče specialne didaktike ali z idejnimi pristopi v visokošolskem izobraževanju. Ker se temeljni cilji in učni izidi povezujejo s kompetencami, Merila za akreditacijo (2014) v drugih členih pravzaprav odrejajo ugotavljanje skladnosti kompetenc študijskega programa s splošnimi kompetencami posameznih vrst in stopenj študija, ki jih v 33. členu opredeljuje ZViS (2017), ne pa kakovosti.

Čeprav nacionalni predpisi zahtevajo občutljivost presoj kakovosti za stopnje in vrste študija, jih postavljajo v ozek kvalifikacijski okvir. Zahtevnost študija sicer stopnjujejo, a ga s ponavljanjem generičnih kompetenc in njihovo podobnostjo tudi uniformirajo. Kljub pomembnemu rezu med drugo in tretjo stopnjo, ko študij preide s strokovne na znanstveno raven, ostajajo podlage za razločevanje med modalnostmi študija pri presojah pomanjkljive. Ker tudi visokošolska didaktika o tej problematiki ni ponudila pomembnih razprav, se v praksi strokovnjaki pri presojah ne morejo zateči niti $\mathrm{k}$ jasnim specifikacijam niti k idealom, po katerih bi bilo mogoče razlikovati, da je na primer visokošolski strokovni študij na prvi stopnji aplikativen, univerzitetni pa temeljen in namenjen nadaljnjemu študiju; da je prvemu posebej pomembno usposabljanje, drugemu pa omika; da se prvi nagiba k posredovanju zaprtega in stabilnega znanja, drugi pa odprtega in pluralnega; da prvi razvija strokovnost v povezavi z delovnim okoljem in na njem poučujejo tudi učitelji iz stroke brez akademskega habitusa, drugi pa skrbi za zgodnji razvoj akademskega habitusa, razgledanost in kulturnost. Predpisi pravzaprav dopuščajo, da se prvine enega in drugega študija prepletajo in jima določajo podobne kompetence, ločnico pa potegnejo zgolj pri tem, da je prvi praktično zasnovan, drugi pa bolj teoretski (ZViS, 2017; Eurydice, b. d.). 


\section{EMPIRIČNI DEL}

Raziskava občutljivosti evalvacijskih praks za vrste, stopnje in področja študijskih programov je nastala kot del širše raziskave kakovosti v terciarnem izobraževanju in lastnosti evalvacijskih praks v sklopu periodične sistemske analize Agencije. Črpa iz javno dostopnih končnih evalvacijskih poročil strokovnjakov v postopkih podaljšanja akreditacije 485 študijskih programov, o katerih je svet Agencije sprejel končno odločitev v obdobju od 2014 do 2017 (Spletni arhiv Nacionalne agencije Republike Slovenije za kakovost v visokem šolstvu, b. d.). Ugotavlja, katerim spremenljivkam kakovosti so strokovnjaki posvečali več pozornosti in katerim manj glede na to, ali je bila določena lastnost oziroma stanje vredno njihovega kvalitativnega poudarka (Širok, 2018). ${ }^{5}$ Njen namen je odgovoriti na vprašanje, koliko so strokovnjaki občutljivi za razlike med stopnjami in vrstami študijskih programov ter disciplinami, v katere so študijski programi vpeti. Odgovoriti pa skuša tudi, kako na to vpliva področna primernost strokovnjakov.

Ker so bili vzorec, zbiranje podatkov, njihova interpretacija ter s tem povezana pravila in lastnosti rezultatov raziskave že predstavljeni (Širok, 2019), spomnimo le na njeno usmerjenost v kvalitativne poudarke, ki so jih strokovnjaki v poročilih za 30 opisnih spremenljivk razvrščali med tri kategorije - prednosti, priložnosti za izboljšanje in neskladnosti (s predpisi). Vseh spremenljivk niso vselej obravnavali s poudarkom znotraj ene od treh kategorij, zato se je za vsako spremenljivko dodatno spremljala četrta kategorija $n i$ obravnavano. Izbrane spremenljivke se opirajo na določila Meril za akreditacijo (2014) in so bistvene za področje organizacije, vsebine in izvajanja študijskih programov, ki je neposredno povezano s posebnostmi stopenj in vrst študijskih programov ter njihovih matičnih disciplin.

Pridobljena baza podatkov ponuja rezultate za študijske programe kot razmerja med štirimi kategorijami za vsako spremenljivko posebej (Širok, 2019). Za filtriranje rezultatov po stopnji in vrsti študijskega programa so bile kot kategorije uporabljene vse stopnje in vrste študijskih programov po ZViS (2017). Klasifikacija študijskih programov (Klasius-P, b. d.) po dveh klasifikacijskih ravneh je bila povzeta iz eVŠ evidence visokošolskih zavodov in študijskih programov (2017) za december 2017 in povezana s frascatsko klasifikacijo (Javna agencija za raziskovalno dejavnost Republike Slovenije, b. d.). Na podlagi primerov in raziskovalnih rezultatov o klasifikaciji disciplin po Biglan (1973), Kolb (1981) ter Becher in Trowler (2001) so bile kategorije povezanosti področij študijskih programov s skupinami disciplin na kognitivni ravni oblikovane po naslednji konvenciji:

Pretežno trde discipline so povezane s študijskimi programi z naslednjih področij: 42 vede o živi naravi; 44 vede o neživi naravi; 46 matematika in statistika; 48 računalništvo; 52 tehniške vede; 54 proizvodne tehnologije; 58 arhitektura in gradbeništvo; 62 kmetijstvo,

5 Oznaka spremenljivka kakovosti je načrtno uporabljena namesto oznake kazalnik kakovosti, saj se slednja pri zagotavljanju kakovosti tendenčno uporablja kot merljiva spremenljivka. Spremenljivke, zajete v pričujočo raziskavo, pa na ravni zunanjih evalvacij študijskih programov niso bile predmet meritev, temveč vrednostnih sodb o kakovosti. 
gozdarstvo in ribištvo; 64 veterinarstvo; 72 zdravstvo; 85 varstvo okolja. ${ }^{6}$ Pretežno mehke discipline so povezane s področji po Klasius-P oziroma s študijskimi programi z naslednjih področij: 14 izobraževalne vede in izobraževanje učiteljev; 21 umetnost; 22 humanistične vede; 31 družboslovne vede; 32 novinarstvo in informiranje; 34 poslovne in upravne vede; 38 pravo; 58 arhitektura in gradbeništvo; 72 zdravstvo; 76 socialno delo; 81 osebne storitve; 84 transportne storitve; 86 varnost. ${ }^{7}$ Pretežno čiste discipline so povezane s področji po Klasius-P oziroma s študijskimi programi z naslednjih področij: 21 umetnost; 22 humanistične vede; 31 družbene vede; 42 vede o živi naravi; 44 vede o neživi naravi; 46 matematika in statistika. ${ }^{8}$ Pretežno aplikativne discipline so povezane s področji po Klasius-P oziroma s študijskimi programi z naslednjih področij: 14 izobraževalne vede in izobraževanje učiteljev; 31 družbene vede; 32 novinarstvo in informiranje; 34 poslovne in upravne vede; 38 pravo; 48 računalništvo; 52 tehniške vede; 54 proizvodne tehnologije; 58 arhitektura in gradbeništvo; 62 kmetijstvo, gozdarstvo in ribištvo; 64 veterinarstvo; 72 zdravstvo; 76 socialno delo; 81 osebne storitve; 84 transportne storitve; 85 varstvo okolja; 86 varnost.

Za filtriranje rezultatov po področni primernosti sestave skupine strokovnjakov sta bili kot kategoriji uporabljeni ujemanje strokovnjakov in neujemanje strokovnjakov, in sicer na podlagi javno dostopnih podatkov o področjih raziskovalne dejavnosti v bazi Informacijskega sistema o raziskovalni dejavnosti v Sloveniji SICRIS (b. d.) in tujih raziskovalnih bazah, med katere zaradi pretežno hrvaške zasedbe tujih strokovnjakov sodita predvsem Tko je tko u hrvatskoj znanosti (b. d.) in Hrvatska znanstvena bibliografija CROSBI (b. d.), ter podatkov o pedagoški dejavnosti, torej o področjih izvolitve v naziv oziroma nosilstvu in izvajanju predmetov, dostopnih na spletnih straneh visokošolskih zavodov. V prvo kategorijo so bile razporejene skupine strokovnjakov, za katere je mogoče vse člane, ki niso študenti, po akademski dejavnosti neposredno povezati s področjem študijskega programa po dveh klasifikacijskih ravneh Klasius-P, v drugo pa skupine strokovnjakov, v katerih nobenega od strokovnjakov, ki ni študent, ni mogoče neposredno povezati s področjem študijskega programa.

\section{REZULTATI IN INTERPRETACIJE}

Občutljivost evalvacijskih praks za posebnosti študija je mogoče izluščiti iz primerjave razlik med največjimi in najmanjšimi vrednostmi za posamezne kategorije kvalitativnih sodb - kako različno so torej strokovnjaki pri posameznih spremenljivkah poudarjali prednosti, priložnosti za izboljšanje oziroma neskladnosti za skupine študijskih programov,

6 Področje 72 se ponovi tudi pri mehkih disciplinah, ker je 13 študijskih programov vpetih v mehke discipline (npr. zdravstvena nega, babištvo, fizioterapija), 15 pa v trde (npr. medicina, dentalna medicina, farmacija). Področje 58 se ponovi tudi pri mehkih disciplinah, saj je 10 študijskih programov povezanih z mehkimi disciplinami (npr. arhitektura, urbanizem), 12 pa s trdimi (npr. gradbeništvo).

7 Področje 21 Biglan (1973) in Kolb (1981) obravnavata kot disciplino, frascatski sistem pa ne.

8 Področje 31 se ponovi tudi pri aplikativnih disciplinah, saj je 32 študijskih programov vpetih v aplikativne discipline (npr. finance, marketing, ekonomija), 21 pa v čiste (npr. sociologija kulture, družbena geografija). Nekateri so razpeti med čiste in aplikativne, npr. študijski programi s področja psihologije. 
filtrirane po stopnjah, vrstah, skupinah disciplin in področni primernosti strokovnjakov. Za poenostavitev prikaza so kvalitativne sodbe postavljene v razmerje razlike med deleži prednosti ter vsoto deležev priložnosti za izboljšanje in neskladnosti. To razmerje, ki za izbrane spremenljivke povprečno znaša $-3,36 \%$, je mogoče razumeti kot stopnjo kritičnosti, katere pozitivna vrednost pomeni presežek deleža prednosti, negativna pa presežek vsote deležev priložnosti za izboljšanje in neskladnosti. Prikaz rezultatov je razširjen s podatki o deležih obravnavanosti posameznih spremenljivk, ki v povprečju znaša 29,03 \%. To pomeni, da v prek $70 \%$ študijskih programov povprečna spremenljivka $n i$ bila obravnavana kot vrednostna sodba - ni bila označena s kvalitativnim poudarkom. Prikaz največjih razlik po posameznih skupinah filtriranih podatkov sporoča, kakšen je bil razpon med podskupino študijskih programov posamezne kategorije (npr. stopnje, vrste ali discipline) z najnižjo stopnjo kritičnosti oziroma obravnavanosti in podskupino z največjo vrednostjo.

Tabela 1: Ranžirna vrsta za stopnjo kritičnosti presoj po posameznih spremenljivkah s prikazom največjih odstopanj za posamezne skupine podatkov, razširjena s pripadajočimi podatki o obravnavanosti

\begin{tabular}{|c|c|c|c|c|c|c|c|c|}
\hline \multirow[b]{2}{*}{ Spremenlijka } & \multicolumn{4}{|c|}{$\begin{array}{l}\text { Razlika med prednostmi ter } \\
\text { vsoto priložnosti in neskladnosti }\end{array}$} & \multicolumn{4}{|c|}{ Ni obravnavano } \\
\hline & $\begin{array}{l}\text { Vsi pro- } \\
\text { grami }(\mathrm{N} \\
=485)\end{array}$ & \begin{tabular}{|l|} 
Največja \\
razlika za \\
stopnjo in \\
vrsto
\end{tabular} & $\begin{array}{l}\text { Največja } \\
\text { razlika za } \\
\text { disciplino }\end{array}$ & $\begin{array}{l}\text { Največja } \\
\text { razlika za } \\
\text { ujemanje } \\
\text { strokov- } \\
\text { njakov }\end{array}$ & $\begin{array}{l}\text { Vsi pro- } \\
\text { grami (N } \\
=485 \text { ) }\end{array}$ & \begin{tabular}{|l|} 
Največja \\
razlika za \\
stopnjo in \\
vrsto
\end{tabular} & $\begin{array}{l}\text { Največja } \\
\text { razlika za } \\
\text { disciplino }\end{array}$ & $\begin{array}{l}\text { Največja } \\
\text { razlika za } \\
\text { ujemanje } \\
\text { strokov- } \\
\text { njakov }\end{array}$ \\
\hline $\begin{array}{l}\text { Zadovoljevanje potreb } \\
\text { okolja po znanju (inte- } \\
\text { lektualna vpetost v širšo } \\
\text { skupnost) }\end{array}$ & $56,12 \%$ & $24,51 \%$ & $11,23 \%$ & $6,90 \%$ & \begin{tabular}{l|l} 
& $22,89 \%$ \\
\end{tabular} & $25,86 \%$ & $3,10 \%$ & $5,28 \%$ \\
\hline $\begin{array}{l}\text { Spremembe in posodo- } \\
\text { bitve vsebin študijskega } \\
\text { programa (ŠP) }\end{array}$ & $28,22 \%$ & $27,52 \%$ & $11,58 \%$ & $0,99 \%$ & $57,11 \%$ & $24,69 \%$ & $12,22 \%$ & $15,39 \%$ \\
\hline $\begin{array}{l}\text { Sodelovanje z gospodar- } \\
\text { stvom na področju izobra- } \\
\text { ževanja }\end{array}$ & $21,24 \%$ & $40,37 \%$ & $12,15 \%$ & $18,20 \%$ & $61,86 \%$ & $23,20 \%$ & $16,91 \%$ & $30,16 \%$ \\
\hline $\begin{array}{l}\text { Zadovoljevanje potreb po } \\
\text { znanju za javne storitve in } \\
\text { javno dobro }\end{array}$ & $18,76 \%$ & $16,40 \%$ & $12,85 \%$ & $5,79 \%$ & $79,18 \%$ & $13,17 \%$ & $13,62 \%$ & $9,71 \%$ \\
\hline Kompetence diplomantov & $17,11 \%$ & $13,44 \%$ & $14,93 \%$ & $0,84 \%$ & $57,32 \%$ & $18,21 \%$ & $4,92 \%$ & $3,29 \%$ \\
\hline Izobraženost diplomantov & $16,70 \%$ & $21,24 \%$ & $13,77 \%$ & $10,78 \%$ & $76,70 \%$ & $18,01 \%$ & $13,67 \%$ & $13,88 \%$ \\
\hline $\begin{array}{l}\text { Interdisciplinarnost študii- } \\
\text { skih vsebin }\end{array}$ & $1,44 \%$ & $15,02 \%$ & $9,63 \%$ & $13,18 \%$ & $88,66 \%$ & $8,88 \%$ & $8,18 \%$ & $3,49 \%$ \\
\hline $\begin{array}{l}\text { Spremembe obsega in } \\
\text { razporeditve izvajanja } \\
\text { kontaktnih ur }\end{array}$ & $0,82 \%$ & $3,50 \%$ & $2,83 \%$ & $0,39 \%$ & $98,76 \%$ & $1,36 \%$ & $2,25 \%$ & $0,39 \%$ \\
\hline $\begin{array}{l}\text { Spremembe načina ali } \\
\text { oblike izvajanja ŠP }\end{array}$ & $0,41 \%$ & $1,26 \%$ & $1,02 \%$ & $0,00 \%$ & $99,59 \%$ & $1,26 \%$ & $1,02 \%$ & $0,00 \%$ \\
\hline
\end{tabular}




\begin{tabular}{|c|c|c|c|c|c|c|c|c|}
\hline \multirow[b]{2}{*}{ Spremenliivka } & \multicolumn{4}{|c|}{$\begin{array}{l}\text { Razlika med prednostmi ter } \\
\text { vsoto priložnosti in neskladnosti }\end{array}$} & \multicolumn{4}{|c|}{ Ni obravnavano } \\
\hline & $\begin{array}{l}\text { Vsi pro- } \\
\text { grami (N } \\
=485)\end{array}$ & $\begin{array}{l}\text { Največja } \\
\text { razlika za } \\
\text { stopnjo in } \\
\text { vrsto }\end{array}$ & $\begin{array}{l}\text { Največja } \\
\text { razlika za } \\
\text { disciplino }\end{array}$ & $\begin{array}{l}\text { Največja } \\
\text { razlika za } \\
\text { ujemanje } \\
\text { strokov- } \\
\text { njakov }\end{array}$ & $\begin{array}{l}\text { Vsi pro- } \\
\text { grami ( } \mathrm{N} \\
=485)\end{array}$ & $\begin{array}{l}\text { Največja } \\
\text { razlika za } \\
\text { stopnjo in } \\
\text { vrsto }\end{array}$ & $\begin{array}{l}\text { Največja } \\
\text { razlika za } \\
\text { disciplino }\end{array}$ & $\begin{array}{l}\text { Največja } \\
\text { razlika za } \\
\text { ujemanje } \\
\text { strokov- } \\
\text { njakov }\end{array}$ \\
\hline $\begin{array}{l}\text { Skladnost vsebine ŠP z } \\
\text { njegovo stopnjo in vrsto }\end{array}$ & $0,21 \%$ & $6,42 \%$ & $1,02 \%$ & $6,78 \%$ & $93,20 \%$ & $2,93 \%$ & $5,09 \%$ & $3,64 \%$ \\
\hline $\begin{array}{l}\text { Povezanost učnih izidov } \\
\text { in kompetenc z ravnjo } \\
\text { znanja, socializacije in } \\
\text { subjektifikacije }\end{array}$ & $-1,45 \%$ & $14,00 \%$ & $3,93 \%$ & $2,74 \%$ & $97,32 \%$ & $9,72 \%$ & $3,31 \%$ & $5,10 \%$ \\
\hline $\begin{array}{l}\text { Skladnost vsebine ŠP z } \\
\text { njegovim področjem in } \\
\text { disciplino }\end{array}$ & $-1,65 \%$ & $7,77 \%$ & $2,03 \%$ & $3,64 \%$ & $86,80 \%$ & $11,96 \%$ & $10,46 \%$ & $3,69 \%$ \\
\hline $\begin{array}{l}\text { Način ali oblika izvajanja } \\
\text { ŠP (glede na število vpisa- } \\
\text { nih, ciklično, na daljavo, } \\
\text { kombinirano) } \\
\end{array}$ & $-3,71 \%$ & $17,73 \%$ & $8,69 \%$ & $9,52 \%$ & $84,33 \%$ & $21,96 \%$ & $16,71 \%$ & $2,00 \%$ \\
\hline $\begin{array}{l}\text { Upoštevanje pobud štu- } \\
\text { dentov za spremembe ŠP }\end{array}$ & $-4,33 \%$ & $22,28 \%$ & $12,39 \%$ & $4,32 \%$ & $63,09 \%$ & $26,28 \%$ & $16,55 \%$ & $21,62 \%$ \\
\hline $\begin{array}{l}\text { Sodelovanje z zunanjimi } \\
\text { akademiki, znanstveniki, } \\
\text { strokovnjaki ali umetniki s } \\
\text { področja ali discipline pri } \\
\text { prenovi ŠP }\end{array}$ & $-4,53 \%$ & $6,52 \%$ & $4,79 \%$ & $1,06 \%$ & $95,05 \%$ & $6,53 \%$ & $5,38 \%$ & $1,06 \%$ \\
\hline $\begin{array}{l}\text { Prilagojenost izvajanja ŠP } \\
\text { potrebam študentov }\end{array}$ & $-4,54 \%$ & $37,95 \%$ & $3,60 \%$ & $3,25 \%$ & $75,26 \%$ & $19,11 \%$ & $13,07 \%$ & $5,02 \%$ \\
\hline $\begin{array}{l}\text { Zaposlijust oz. zaposle- } \\
\text { nost diplomantov }\end{array}$ & $-8,45 \%$ & $25,44 \%$ & $13,88 \%$ & $3,26 \%$ & $37,94 \%$ & $12,19 \%$ & $13,08 \%$ & $9,17 \%$ \\
\hline $\begin{array}{l}\text { Izvajanje kontaktnih ur, } \\
\text { niihov obseg in } \\
\text { razporeditev }\end{array}$ & $-10,31 \%$ & $20,93 \%$ & $9,23 \%$ & $5,32 \%$ & $60,41 \%$ & $25,22 \%$ & $7,20 \%$ & $7,58 \%$ \\
\hline $\begin{array}{l}\text { Prilagojenost vsebin ŠP } \\
\text { potrebam gospodarstva }\end{array}$ & $-11,75 \%$ & $16,90 \%$ & $18,11 \%$ & $1,15 \%$ & $65,36 \%$ & $36,71 \%$ & $16,08 \%$ & $0,61 \%$ \\
\hline Zahtevnost študija & $-11,75 \%$ & $16,84 \%$ & $11,29 \%$ & $12,24 \%$ & $68,45 \%$ & $10,60 \%$ & $14,30 \%$ & $13,23 \%$ \\
\hline $\begin{array}{l}\text { Preverljivost učnih izidov in } \\
\text { kompetenc }\end{array}$ & $-11,96 \%$ & $11,70 \%$ & $13,57 \%$ & $7,47 \%$ & $69,90 \%$ & $13,16 \%$ & $4,50 \%$ & $8,56 \%$ \\
\hline \begin{tabular}{|l|} 
Skladnost vsebine ŠP z \\
njegovimi cilii, znanii, kom- \\
petencami in učnimi izidi
\end{tabular} & $-14,43 \%$ & $35,00 \%$ & $22,91 \%$ & $11,10 \%$ & $53,40 \%$ & $6,92 \%$ & $16,02 \%$ & $7,30 \%$ \\
\hline $\begin{array}{l}\text { Obvezne sestavine študii- } \\
\text { skega programa, ki se ne } \\
\text { tikajo kurikula }\end{array}$ & $-15,04 \%$ & $3,90 \%$ & $7,88 \%$ & $8,66 \%$ & $79,18 \%$ & $5,32 \%$ & $3,25 \%$ & $4,76 \%$ \\
\hline \begin{tabular}{|l|}
$\begin{array}{l}\text { Sodelovanje z delodajalci } \\
\text { pri prenovi ŠP }\end{array}$ \\
\end{tabular} & $-15,46 \%$ & $10,54 \%$ & $17,17 \%$ & $7,08 \%$ & $70,52 \%$ & $10,06 \%$ & $16,77 \%$ & $5,93 \%$ \\
\hline $\begin{array}{l}\text { Prilagojenost vsebin ŠP } \\
\text { potrebam študentov }\end{array}$ & $-16,29 \%$ & $32,05 \%$ & $9,26 \%$ & $0,35 \%$ & $58,35 \%$ & $39,68 \%$ & $11,64 \%$ & $13,46 \%$ \\
\hline
\end{tabular}




\begin{tabular}{|c|c|c|c|c|c|c|c|c|}
\hline \multirow[b]{2}{*}{ Spremenliivka } & \multicolumn{4}{|c|}{$\begin{array}{l}\text { Razlika med prednostmi ter } \\
\text { vsoto priložnosti in neskladnosti }\end{array}$} & \multicolumn{4}{|c|}{ Ni obravnavano } \\
\hline & $\begin{array}{l}\text { Vsi pro- } \\
\text { grami (N } \\
=485)\end{array}$ & $\begin{array}{l}\text { Največja } \\
\text { razlika za } \\
\text { stopnjo in } \\
\text { vrsto }\end{array}$ & $\begin{array}{l}\text { Največja } \\
\text { razlika za } \\
\text { disciplino }\end{array}$ & $\begin{array}{l}\text { Največja } \\
\text { razlika za } \\
\text { ujemanje } \\
\text { strokov- } \\
\text { njakov }\end{array}$ & $\begin{array}{l}\text { Vsi pro- } \\
\text { grami (N } \\
=485)\end{array}$ & $\begin{array}{l}\text { Največja } \\
\text { razlika za } \\
\text { stopnjo in } \\
\text { vrsto }\end{array}$ & $\mid \begin{array}{l}\text { Največja } \\
\text { razlika za } \\
\text { disciplino }\end{array}$ & $\begin{array}{l}\text { Največja } \\
\text { razlika za } \\
\text { ujemanje } \\
\text { strokov- } \\
\text { njakov }\end{array}$ \\
\hline $\begin{array}{l}\text { Učni izidi in kompetence } \\
\text { ter njihova povezanost z } \\
\text { zaposlijivostjo }\end{array}$ & $-18,35 \%$ & $9,58 \%$ & $8,54 \%$ & $1,00 \%$ & $73,40 \%$ & $6,61 \%$ & $6,58 \%$ & $3,32 \%$ \\
\hline Dovršenost strukture ŠP & $-18,77 \%$ & $27,32 \%$ & $7,00 \%$ & $13,13 \%$ & $73,61 \%$ & $22,67 \%$ & $8,33 \%$ & $3,21 \%$ \\
\hline $\begin{array}{l}\text { Zadovolievanje potreb } \\
\text { trga dela }\end{array}$ & $-21,85 \%$ & $9,77 \%$ & $11,93 \%$ & $1,12 \%$ & $71,13 \%$ & $3,10 \%$ & $14,62 \%$ & $3,45 \%$ \\
\hline $\begin{array}{l}\text { Krepitev kompetenc za } \\
\text { delovno mesto }\end{array}$ & $-29,07 \%$ & $33,01 \%$ & $13,91 \%$ & $18,21 \%$ & $54,43 \%$ & $43,07 \%$ & $14,89 \%$ & $3,27 \%$ \\
\hline $\begin{array}{l}\text { Skladnost vsebine ŠP z } \\
\text { njenim kreditnim vredno- } \\
\text { tenjem }\end{array}$ & $-38,14 \%$ & $31,69 \%$ & $16,76 \%$ & $15,55 \%$ & $55,88 \%$ & $32,14 \%$ & $16,76 \%$ & $22,20 \%$ \\
\hline Povprečje & $-3,36 \%$ & $18,69 \%$ & $10,26 \%$ & $6,47 \%$ & $70,97 \%$ & $16,69 \%$ & $10,35 \%$ & $7,66 \%$ \\
\hline Standardni odklon & $18,63 \%$ & $10,89 \%$ & $5,37 \%$ & $5,51 \%$ & $17,95 \%$ & $11,49 \%$ & $5,32 \%$ & $7,18 \%$ \\
\hline
\end{tabular}

Vir: osebne analize

Pri razumevanju rezultatov je treba upoštevati, da se z zviševanjem stopnje obravnavanosti večajo odstopanja od nične vrednosti stopnje kritičnosti. Pogled na razvrstitve rezultatov kaže, da se z večanjem negativnosti stopnje kritičnosti raznoličnost kvalitativnih poudarkov po stopnjah, vrstah in skupinah disciplin skoraj ne povečuje, nekoliko bolj pa se raznoličnost $\mathrm{v}$ obravnavanosti povečuje $\mathrm{z}$ zviševanjem stopnje obravnavanosti spremenljivk. Enako velja tudi za razlike v kvalitativnih poudarkih in obravnavanosti glede na področno primernost skupin strokovnjakov. Za interpretacijo rezultatov je ključno, da se $\mathrm{z}$ večanjem razlik $\mathrm{v}$ obravnavanosti in stopnji kritičnosti znotraj posameznih skupin filtriranih podatkov veča občutljivost presoj strokovnjakov za posebnosti stopnje, vrste in disciplinarne vpetosti študija. Posamezne spremenljivke imajo namreč za različne posebnosti študija različne implikacije in pomen, čeprav so lahko izpeljane iz univerzalnih specifikacij. Z upadanjem razlik so torej strokovnjaki do posameznih vprašanj ne glede na njihovo specifiko kot na zadevne posebnosti študija vse bolj enako kritični in se jim vse bolj enako posvečajo - s svojimi presojami tako pomagajo študij uniformirati.

Odstopanja v stopnji kritičnosti so med študijskimi programi različne stopnje in vrste $\mathrm{v}$ povprečju $(18,69 \%)$ občutno večja kot med študijskimi programi, vpetimi v discipline različnih skupin $(10,26 \%)$. V povprečju so razlike v razmerju med kvalitativnimi poudarki najmanjše glede na področno primernost sestave skupine strokovnjakov (zgolj 6,47 \%). Enako velja za obravnavanost spremenljivk, ki v povprečju najbolj variira med različnimi stopnjami in vrstami študijskih programov $(16,69 \%)$, manj med študijskimi programi, ki pripadajo različnim skupinam disciplin $(10,35 \%)$, najmanj pa glede na področno primernost sestave skupine strokovnjakov $(7,66 \%)$. 
Če rezultate tako za obravnavanost spremenljivk kot za stopnjo kritičnosti presoj razvrstimo po razponu občutljivosti strokovnjakov za presojo disciplinarnih posebnosti študijskih programov, največjo variacijo kažejo spremenljivke, ki se tikajo participacije (predvsem zunanjih) agensov pri vprašanjih vsebine in izvajanja študija; kompetenc za delovno mesto in kompetenc diplomantov. Bolj homogena pa je obravnava spremenljivk, povezanih z intrinzičnimi lastnostmi študija - z njegovo vsebino glede na cilje, stopnjo, vrsto, vpetost v disciplino; z njegovim izvajanjem in obveznimi sestavinami. Podobno dihotomijo med spremenljivkami pokaže tudi razvrstitev razlik v obravnavanosti in stopnji kritičnosti za študijske programe različnih stopenj in vrst: $\mathrm{v}$ nasprotju $\mathrm{z}$ rezultatsko razgibanimi spremenljivkami, usmerjenimi v potrebe in pričakovanja okolja oziroma agensov, so spremenljivke, ki zadevajo intrinzične lastnosti študija, uravnoteženo obravnavane in primerljivo kritično presojane.

Razvrstitev rezultatov glede na področno primernost strokovnjakov temu trendu ne sledi, saj se v robnih tercilih pojavljajo spremenljivke, ki zajemajo tako intrinzične kot ekstrinzične dejavnike študija. Tako so strokovnjaki ne glede na svoj disciplinarni habitus bolj občutljivi za uporabnost in funkcionalnost študija (kakovost kot ustreznost namenu), katerima se obenem tudi pogosteje posvečajo. Zanašanje instrumenta kakovosti na področno primernost strokovnjakov pa $\mathrm{v}$ praksi ne kompenzira uspešno neobčutljivosti specifikacij za intrinzične posebnosti študija.

Če spremenljivke razporedimo $\mathrm{v}$ skupine, ki jih povezujejo različne konceptualne predispozicije; ${ }^{9}$ usmerjenost bodisi v potrjevanje skladnosti bodisi v presojo kakovosti; lastnost merljivosti ali nemerljivosti; stopnja predpisanosti; ${ }^{10}$ deloma pa tudi usmerjenost $\mathrm{v}$ presojo pogojev, procesov ali končnih stanj, se v obeh tercilih tako za stopnje in vrste kot za disciplinarno vpetost študijskih programov pojavljajo spremenljivke, ki znotraj svojih skupin pripadajo različnim modalnostim. Presoja po njih je zato z vidika modalnosti pretežno homogena, tudi glede na področno primernost strokovnjakov. Izjema je raznoličnost spremenljivk glede na stopnjo njihove obravnavanosti. Pod vplivom zgoraj omenjenega razmerja med stopnjo obravnavanosti in odstopanjem stopnje kritičnosti od nične vrednosti se z zviševanjem stopnje obravnavanosti sorazmerno veča tudi občutljivost presoj strokovnjakov za posebnosti študija.

9 Gre za izbrane esencialistične koncepte kakovosti, zajete v raziskavo evalvacijskih praks. Mednje na eni strani sodita kakovost kot ustreznost namenu in kakovost kot popolnost oziroma skladnost, na drugi pa akademska kakovost in ekonomistični, tehnokratski oziroma konstruktivistični pristop h kakovosti (Širok, 2019).

10 Gre za členitev spremenljivk v tri skupine glede na to, ali so neposredno oziroma izrecno predpisane v Merilih za akreditacijo (2014), ali so v predpisu zgolj posredno, vendar ne izrecno nakazane, ali pa v njem nimajo podlage. 
Tabela 2: Rezultati za vse spremenliivke po posameznih skupinah študijskih programov, kategorijah kvalitativnih sodb in obravnavanosti

\begin{tabular}{|c|c|c|c|c|c|}
\hline & Prednost & $\begin{array}{l}\text { Priložnost za } \\
\text { izboljšanje }\end{array}$ & Neskladnost & $\begin{array}{l}\text { Ni obravna- } \\
\text { vano }\end{array}$ & $\begin{array}{l}\text { Razlika med } \\
\text { prednostmi } \\
\text { ter vsoto } \\
\text { priložnosti in } \\
\text { neskladnosti }\end{array}$ \\
\hline VS. 1. st. $(N=65)$ & $12,92 \%$ & $14,82 \%$ & $0,56 \%$ & $71,69 \%$ & $-2,46 \%$ \\
\hline UN. 1. st. $(N=159)$ & $12,62 \%$ & $18,20 \%$ & $0,19 \%$ & $68,99 \%$ & $-5,77 \%$ \\
\hline $\begin{array}{l}\text { MAG. in enoviti MAG. } \\
\text { 2. st. }(N=190)\end{array}$ & $13,56 \%$ & $15,11 \%$ & $0,63 \%$ & $70,68 \%$ & $-2,18 \%$ \\
\hline DR. 3. st. $(N=62)$ & $10,70 \%$ & $13,65 \%$ & $0,22 \%$ & $75,54 \%$ & $-3,28 \%$ \\
\hline $\begin{array}{l}\text { Trde discipline } \\
(N=197)\end{array}$ & $14,10 \%$ & $16,72 \%$ & $0,22 \%$ & $68,98 \%$ & $-2,91 \%$ \\
\hline $\begin{array}{l}\text { Mehke discipline } \\
(\mathrm{N}=344)\end{array}$ & $11,99 \%$ & $15,24 \%$ & $0,49 \%$ & $72,26 \%$ & $-3,75 \%$ \\
\hline $\begin{array}{l}\text { Čiste discipline } \\
(N=226)\end{array}$ & $12,85 \%$ & $16,49 \%$ & $0,59 \%$ & $70,06 \%$ & $-4,23 \%$ \\
\hline $\begin{array}{l}\text { Aplikativne discipline } \\
(\mathrm{N}=322)\end{array}$ & $12,93 \%$ & $14,99 \%$ & $0,50 \%$ & $71,57 \%$ & $-2,56 \%$ \\
\hline $\begin{array}{l}\text { Ujemanje strokovnjakov } \\
(\mathrm{N}=255)\end{array}$ & $13,44 \%$ & $14,99 \%$ & $0,65 \%$ & $70,90 \%$ & $-2,21 \%$ \\
\hline $\begin{array}{l}\text { Neujemanje } \\
\text { strokovnjakov }(\mathrm{N}=59)\end{array}$ & $14,52 \%$ & $16,27 \%$ & $0,28 \%$ & $68,93 \%$ & $-2,03 \%$ \\
\hline $\begin{array}{l}\text { Vsi programi } \\
(\mathrm{N}=485)\end{array}$ & $12,82 \%$ & $15,78 \%$ & $0,41 \%$ & $70,97 \%$ & $-3,36 \%$ \\
\hline$\Delta$ Stopnje in vrste & $2,86 \%$ & $4,55 \%$ & $0,44 \%$ & $6,55 \%$ & $3,60 \%$ \\
\hline$\Delta$ Discipline & $2,11 \%$ & $1,73 \%$ & $0,37 \%$ & $3,28 \%$ & $1,87 \%$ \\
\hline $\begin{array}{l}\Delta \text { Ujemanje } \\
\text { strokovnjakov }\end{array}$ & $1,08 \%$ & $1,28 \%$ & $0,37 \%$ & $1,97 \%$ & $1,18 \%$ \\
\hline
\end{tabular}

Vir: osebne analize

Razlika znotraj posameznih skupin filtriranih podatkov je za vse kvalitativne kategorije, za stopnjo kritičnosti in za stopnjo obravnavanosti največja med različnimi stopnjami in vrstami študijskih programov, znatno manjša je med študijskimi programi, ki pripadajo različnim skupinam disciplin, najmanjša pa glede na področno primernost sestave skupine strokovnjakov. Medtem ko je mogoče ponovno potrditi ugotovitev, da zanašanje na področno primernost strokovnjakov v praksi nima želenega učinka, se je treba posvetiti tudi deležem priložnosti za izboljšanje v navezi s stopnjo obravnavanosti. Strokovnjaki so do univerzitetnih študijskih programov občutno manj prizanesljivi kot do drugih stopenj 
oziroma vrst študija, pri čemer jim proporcionalno posvečajo tudi največ kvalitativnih poudarkov (najpogosteje jih obravnavajo). Med skupinami disciplin so deleži priložnosti za izboljšanje precej bolj izenačeni, se pa študijski programi, vpeti v trde discipline, ponašajo s proporcionalno več prednostmi in kvalitativnimi poudarki.

Tabela 3: Uvrstitve posameznih skupin študijskih programov po številu spremenliivk glede na povprečne vrednosti

\begin{tabular}{|c|c|c|}
\hline & $\begin{array}{l}\text { Nadpovprečna }(+1) / \\
\text { podpovprečna }(-1) \\
\text { obravnavanost }\end{array}$ & $\begin{array}{l}\text { Nadpovprečna (+1)/ } \\
\text { podpovprečna (-1) razlika } \\
\text { med prednostmi ter vsoto } \\
\text { priložnosti in neskladnosti }\end{array}$ \\
\hline VS. 1. st. $(N=65)$ & $+12 /-14$ & $+16 /-11$ \\
\hline UN. 1. st. $(N=159)$ & $+16 /-9$ & $+10 /-14$ \\
\hline MAG. in enoviti MAG. 2. st. $(N=190)$ & $+12 /-10$ & $+13 /-9$ \\
\hline DR. 3. st. $(\mathrm{N}=62)$ & $+9 /-16$ & $+12 /-17$ \\
\hline Trde discipline $(\mathrm{N}=197)$ & $+20 /-9$ & $+16 /-12$ \\
\hline Mehke discipline $(\mathrm{N}=344)$ & $+7 /-16$ & $+10 /-12$ \\
\hline Čiste discipline $(N=226)$ & $+13 /-11$ & $+9 /-12$ \\
\hline Aplikativne discipline ( $N=322)$ & $+10 /-11$ & $+12 /-7$ \\
\hline
\end{tabular}

Vir: osebne analize

Če se vrnemo na raven posameznih spremenljivk in opazujemo odstopanja od povprečnih vrednosti, so univerzitetni študijski programi prve stopnje pri največ spremenljivkah nadpovprečno obravnavani (16 od 30 spremenljivk) in pogosto nadpovprečno kritično ocenjeni (14 od 30 spremenljivk). Z -17 jih sicer kljub najpogostejši podpovprečni obravnavanosti presenetljivo presegajo doktorski študijski programi. Skupno so visokošolski strokovni študijski programi prve stopnje pri največ spremenljivkah podpovprečno kritično ocenjeni.

Spomnimo na predhodno ugotovitev, da so strokovnjaki ne glede na področno primernost v splošnem bolj občutljivi za uporabnost in funkcionalnost študija. Tudi posvečajo se jima pogosteje kot njegovim intrinzičnim posebnostim. Pogosteje in bolj kritično obravnavane spremenljivke, kot so krepitev kompetenc za delovno mesto, zadovoljevanje potreb trga dela, prilagojenost vsebin študijskega programa potrebam študentov, prilagojenost vsebin študijskega programa potrebam gospodarstva in zaposljivost oziroma zaposlenost diplomantov, so pri univerzitetnih študijskih programih prve stopnje v povprečju pogosteje obravnavane (za povprečje omenjenih petih spremenljivk znaša presežek 12,31 \%) in v povprečju beležijo večje deleže priložnosti za izboljšanje (za povprečje omenjenih petih spremenljivk znaša ta 13,56 \%) kot pri visokošolskih strokovnih študijskih programih. Dodajmo, da znaša povprečna obravnavanost za omenjenih pet spremenljivk za vse 
študijske programe 42,56 \%, povprečen delež priložnosti za izboljšanje pa 29,78 \%. Skoraj tretjinsko povečanje obravnavanosti in skoraj polovično povečanje deleža priložnosti za izboljšanje glede na povprečji za vse študijske programe sta v nasprotju z intrinzičnim namenom prvostopenjskega univerzitetnega študija, saj bi moral ta v nasprotju z visokošolskim strokovnim bolj kot potrebe (zunanjih) agensov zasledovati potrebe matične disciplinarne vednosti.

Na ravni disciplinarne vpetosti študijskih programov so odstopanja od povprečnih vrednosti tako za stopnjo obravnavanosti kot za stopnjo kritičnosti na osi vpetosti v trde/ mehke discipline izrazitejša kot na osi vpetosti v čiste/aplikativne discipline. Na področju presoje kakovosti organizacije, vsebine in izvajanja študija strokovnjaki večkrat nadpovprečno ocenijo študijske programe, povezane s trdimi disciplinami. Medtem ko slednje tudi največkrat nadpovprečno obravnavajo, pa so najmanjkrat nadpovprečno kritični do študijskih programov aplikativnih disciplin. Če se spomnimo, da področni predpisi v ničemer ne ločijo med disciplinarnimi posebnostmi študijskih programov, kakovost v visokem šolstvu v praksi vendarle ni indiferentna za disciplinarno poreklo študija.

\section{SKLEP}

V prispevku smo z empiričnega zornega kota deloma osvetlili občutljivost evalvacijskih praks za posebnosti študija. Pri tem nas je omejevala tesna povezanost med področnimi predpisi in evalvacijami, ki zaznamuje tudi samo besedišče kakovosti in povezane idejne sheme. Te okoliščine se odražajo $\mathrm{v}$ dosegu raziskave - v kompromisni določenosti spremenljivk zaradi zamejitve subjektivnih interpretacij pri pripisovanju posameznih kvalitativnih poudarkov strokovnjakov k posameznim spremenljivkam in kategorijam. Preučevanje občutljivosti presoj je bilo oprto predvsem na predpisane specifikacije. Rezultati raziskave kljub temu nakazujejo na pogojenost občutljivosti presoj za različne stopnje in vrste študija s področnimi predpisi, ki posvečujejo raven kvalifikacije; na neobčutljivost presoj za disciplinarne posebnosti študija; in na okoliščino, da področna primernost skupin strokovnjakov v praksi ne kompenzira uspešno neobčutjivosti specifikacij za posebnosti študija. Čeprav se instrument kakovosti v praksi manifestira kot gibalo standardizacije in transformacije visokošolskega izobraževanja po visokemu šolstvu pretežno zunanjih silnicah, hkrati zavira njegove posebnosti in ukaluplja izrekanje kvalitativnih sodb. Postavlja se vprašanje, ali bi razmere izboljšal esencialistični in na deklariranih vrednotah temelječ koncept kakovosti z razlago posebnosti študija. Postavlja pa se tudi vprašanje, ali ne bi morali za svojevrstnost praks in procesov v visokem šolstvu avtonomno skrbeti visokošolski zavodi sami, ker so to v dolgoletni zgodovini že uspešno počeli, nemara bolje, kot to danes z usklajenimi posegi od zunaj počne instrument kakovosti. 


\section{LITERATURA}

Becher, T. (1994). The Significance of Disciplinary Differences. Studies in Higher Education, 19(2), $151-161$.

Becher, T. in Trowler, P. R. (2001). Academic Tribes and Territories: Intellectual enquiry and the culture of disciplines. Philadelphia: SRHE in Open University Press.

Biesta, J. J. G. (2010). Good Education in an Age of Measurement. Ethics, Politics, Democracy. Boulder in London: Paradigm Publishers.

Biesta, J. J. G. in Bingham, C. (2010). Jacques Rancière: Education, Truth, Emancipation. London in New York: Continuum.

Biglan, A. (1973). The Characteristics of Subject Matter in Different Academic Areas. Journal of Applied Psychology, 57(3), 195-203.

Dilthey, W. (1990). Einleitung in die Geisteswissenschaften: Versuch einer Grundlegung für das Studium der Gesellschaft und der Geschichte. Stuttgart: Teubner Verlagsgesellschaft.

Eurydice. (b.d.). Programi prve stopnje. Pridobljeno s https://eacea.ec.europa.eu/national-policies/ eurydice/content/bachelor-77_sl

eVŠ evidenca visokošolskih zavodov in študijskih programov. (2017). Pridobljeno s http://www. mizs.gov.si/si/delovna_podrocja/direktorat_za_visoko_solstvo/sektor_za_visoko_solstvo/ evs_evidenca_visokosolskih_zavodov_in_studijski_programov/

Freitag, M. (2010). Brodolom univerze in drugi eseji iz politične epistemologije. Ljubljana: Sophia.

Gurung, A. R., Chick, N. L. in Haynie, A. (2009). Exploring Signature Pedagogies: Approaches to Teaching Disciplinary Habits of Mind. Sterling: Stylus Publishing.

Hrvatska znanstvena bibliografija CROSBI. (b.d.). Pridobljeno s https://www.bib.irb.hr/

Informacijski sistem o raziskovalni dejavnosti v Sloveniji SICRIS. (b.d.). Pridobljeno s https://www. sicris.si/public/jqm/cris.aspx?lang=slv\&opdescr=home\&opt=1

Klasius-P. (b.d.). Pridobljeno s https://www.stat.si/klasius/Default.aspx?id=5

Kodelja, Z. (2010). O koncu česa pripovedujejo zgodbe o koncu izobrazbe. Sodobna pedagogika, 61(5), 14-35.

Kolb, D. A. (1981). Learning Styles and Disciplinary Differences. V A. W. Chickering (ur.), The Modern American College (str. 232-255). San Francisco: Jossey-Bass.

Kotnik, R. (2013). Nova paradigma v izobraževanju: Je manj lahko več? Maribor: Subkulturni azil, zavod za umetniško produkcijo in založništvo.

Kuhn, T. S. (1996). The Structure of Scientific Revolutions. Chicago in London: The University of Chicago Press.

Kump, S. (1994). Akademska kultura. Ljubljana: Znanstveno in politično središče.

Merila za akreditacijo in zunanjo evalvacijo visokošolskih zavodov in študijskih programov. (2014). Uradni list RS, št. 40 (6. 6. 2014). Pridobljeno s http://pisrs.si/Pis.web/pregledPredpisa?id=MERI43

Javna agencija za raziskovalno dejavnost Republike Slovenije. (b.d.). Preslikava klasifikacije raziskovalnih področij po šifrantu ARRS v klasifikacijo po Frascatskem priročniku. Pridobljeno s https://www. arrs.si/sl/gradivo/sifranti/sif-vpp-frascati.asp

Scott, P. (2003). Challenges to Academic Values and the Organization of Academic Work in a Time of Globalization. Higher Education in Europe, 28(3), 295-306.

Slovensko ogrodje kvalifikacij. (b.d.). Pridobljeno s https://www.nok.si/

Spletni arhiv Nacionalne agencije Republike Slovenije za kakovost v visokem šolstvu: Poročila strokovnjakov in odločbe. (b.d.). Pridobljeno s https://www.nakvis.si/analize-in-publikacije/ porocila-strokovnjakov-in-odlocbe/ 
Širok, J. (2018). Kakovost kadrov v slovenskem visokem šolstvu od 2014 do 2017. Ljubljana: Nacionalna agencija Republike Slovenije za kakovost v visokem šolstvu.

Širok, J. (2019). Koncepti kakovosti v evalvacijskih praksah v visokem šolstvu: Instrumentalizacija relativistične kakovosti. Andragoška spoznanja, 25(3), 141-160.

Tko je tko u hrvatskoj znanosti. (b.d.). Pridobljeno s http://tkojetko.irb.hr/

Zakon o visokem šolstvu [ZViS]. (2017). Uradni list RS, št. 65/17 (20. 11. 2017). Pridobljeno s http:// pisrs.si/Pis.web/pregledPredpisa?id=ZAKO172 